\title{
INDIGENOUS SOCIAL MOVIMENT AND THE CONQUEST OF THE INTERCULTURAL SCHOOL
}

\author{
O MOVIMENTO SOCIAL INDÍGENA E A CONQUISTA DA ESCOLA INTERCULTURAL \\ MOVIMIENTO SOCIAL INDÍGENA Y LA CONQUISTA DE LA ESCUELA INTERCULTURAL
}

\begin{abstract}
Alceu Zoia
Doctorate in Education from Universidade Federal de Goiás. Adjunct Professor at Universidade do Estado de Mato Grosso and the Graduate Program in Education at Universidade do Estado de Mato Grosso. alceuzoia@gmail.com.
\end{abstract}

0000-0002-0512-9511

\section{Luiz Felipe Sousa Curvo}

Master in Education from Universidade do Estado do Mato Grosso (2020). Librarian-documentalist for the Instituto Federal de Educação, Ciência e Tecnologia do Maranhão, Barra do Corda Campus. luiz.curvo88@gmail.com.

0000-0002-0476-5663

Mailing address: Fundação Universidade do Estado de Mato Grosso, Campus de Sinop. Av. dos Ingás, n 3001 , Centro. 78550-000 - Sinop, MT - Brasil.

Received: 10.12 .2020

Accepted: 11.20.2020.

Published: 01.01.2021.

\begin{abstract}
:
Social movements had great participation as an agent of political changes throughout the 20th century, it is from this articulation (especially in Latin America) that the perspective of interculturality strengths in the indigenous school education, which seeks to understand the school within the post-colonial inequalities. The Brazilian Indigenous Movement began to organize itself in the 1970s, with the Union of Indigenous Nations (UNI) playing a major role in the 1988 constitutional charter, which will underpin the educational rights related to the intercultural school within a specific social Project.
\end{abstract}

KEYWORDS Social movements. Intercultural education. Indigenous peoples.

\section{Introduction}

It is from the organized indigenous action as a social movement, articulated with the perspective of the Latin American context, that the political, cultural and educational goals will be present in the concept of intercultural school, which has as a principle the protagonismo of the indigenous people.

A landmark that represents the legal overcoming of the idea of assimilation of indigenous peoples and the reaffirmation of the right to school education that values cultural diversity and the corporate project of each people. It is the 1988 constitutional the first prevew the decisive participation by the movement indigenous.

So, the school, historically used as a form of doctrination and assimilation of the indigenous within a process of deterritorialization and denial of their culture, proves to be an important instrument for valuing ethnic and cultural identity.

\section{Development}

The twentieth century saw several social movements linked to popular struggles flourishing in Brazil and Latin America. Under the climate of the 1948 Declaration of Human Rights, which recognized rights and freedoms, a series of flags and demands 
related to ethnic identities and cultural minorities was emerging. At the international level, it was in 1975 that, for the first time in the history of the indigenous movement, indigenous peoples of 19 nationalities met in Canada to discuss problems that affected them and ways of organizing strategies to address these issues. (BICALHO, 2010).

In Latin America, according to Fleuri (2003, p. 20), "a diversidade cultural foi historicamente relegada e deixada à margem das propostas e práticas educativas que, a exemplo do que ocorreu na Europa, se pautaram no ideal homogeinizador do EstadoNação". Educational policies were, therefore, formed from this ideal of a unique culture in the primordial formation of these policies in Latin American countries, which had, as one of its consequences, the low academic performance of students whose mother tongue was different from that of their mother tongue. used in official education systems. For Fleuri (2003), movements linked to popular culture and popular education began to appear in the 1950s, being silenced and subjected to strict controls from the military dictatorship. These movements started to gain strength again in the 1970s, when several movements (indigenous, blacks, homosexuals, women) emerged that questioned, based on their identity, the current economic and political plans, leading the debate to various conceptions of socio-cultural relations of identity processes, characterized as intercultural.

For Fleuri (2003), the concept of intercultural education gains strength from its political-pedagogical dimension in overcoming the bi-cultural, or multicultural perspective. According to the author (2003, p. 21), "interculturalidade, além de expressar a coesão étnica de um grupo social, proporcionando condições para o fortalecimento da identidade cultural, vai também estimular a aquisição do conhecimento cultural dos outros povos"

This new concept resulted in a major change in the treatment of cultural differences within the school environment, related to the emergence of indigenous identities in the struggle for their rights. Indigenous uprisings in Mexico, Bolivia, Ecuador, Chile, Colombia, Brazil, among others, sought the right of possession over their lands and, consequently, the revaluation of their languages and traditions, which required educational programs adapted to this reality. Fleuri (2003, p. 22) characterizes as "uma nova perspectiva epistemológica que aponta para a compreensão do hibridismo e da ambivalência, que constituem as identidades e relações interculturais". For Fleuri (2003, p. 23):

A intercultura vem se configurando como um objeto de estudo interdisciplinar e transversal, no sentido de tematizar e teorizar a complexidade (para além da pluralidade ou da diversidade) e a 
ambivalência ou o hibridismo (para além da reciprocidade ou da evolução) dos processos de elaboração de significados nas relações intergrupais e intersubjetivas, constitutivos de campos identitários em termos de etnias, de gerações, de gênero e de ação social.

Original cultures are not subordinate to hegemonic movements, and as it is possible to recognize in globalization and in contemporary times, they resist and assert themselves through indigenous social movements. It is importante to understand that the process of cultural Exchange does not make these peoples less indigenous. Many peoples throughout the course of the contact were inclined in favor of mastering techniques and other knowledge that entered the Amerindian continente through western colonialismo, however, not denying their ethnic identity and traditional knowledge. According to Fravre (1998), indigenism itself must be understood not as a pure expression of indigenous thought, but as na eminently syncretic reflection of a resistance generated in this contact.

El movimiento indigenista no es la manifestación de un pensamiento indígena, sino una reflexión criolla y mestiza sobre El índio [...]. Esto no impide que tome decisiones acerca de su destino en sus propios lugares, según los intereses superiores de la nación tal y como son concebidos por los indigenistas. Eso es precisamente lo que reprocha El indianismo, desarrollado a partir del decenio de 1970, el cual pretende ser la expresión de aspiraciones y reivindicaciones auténticamente índias. Por el eco que tiene actualmente en el conjunto de la sociedad, la critica radical a la que el indigenismo es sometido por las organizaciones indianistas manifiesta el derrumbamiento de la coyuntura en la que aquél se expandió (FAVRE, 1998, p. 11).

Based on Bergamaschi (2014), it is considered an understanding of the indigenous as a producer of scientific knowledge, an understanding that does not rank the constitutions of culture, established by intercultural experience that is also of an ethical nature. As science is not free from ideological and utopian disputes related to its results, it is necessary that these intellectuals, representatives of their social movements, interfere in the state in question, since science serving capitalism seeks to increase production and make it cheaper in order to ensure greater profits and the expansion of its markets. It is necessary to counter this pro-capital epistemology and think about science not for the full exploitation of a limited planet, but for there to be a balance with the preserved nature, so that traditional cultures can exercise their freedom. According to Passos (2010, p. 28):

A mercadoria incidiu sobre a vida dos seres humanos, agora destituídos de sua liberdade e autodeterminação, em favor do mercado que se torna vivo e tem a palavra da ordem da vida e da morte dos seres 
humanos, induzindo-os a pura reprodução material de sua existência, expropriados que foram por uma cultura da dominação que minou a liberdade deles.

This results in an epistemological perception that the function of schools in indigenous societies is to assimilate this population and adapt it to the hegemonic culture in its obsession with material production and accumulation. Silva and Herbetta (2017) point to a need for a new epistemic basis that contemplates the reflection on access, permanence and formation of the indigenous, who do not resort to the error of imposing Eurocentric values, reproducing the dynamics of integration of indigenous people into Western society.

For Bicalho (2010), faced with a Latin America that had authoritarian governments and fragile democratic structures, the conquest of rights by the indigenous people proved to be difficult to be achieved, even more considering the little articulation of an Indigenous Movement still to be built in midle of 20th century. During the Military Dictatorship, which lasted from 1964 until 1985, the idea of the Indian was seen as a transitory way, an obstacle to national progress. At this authoritarian moment in the country's history, supporting indigenous demands for its territory and culture was seen as an act of subversion. The dictatorship's national integration policy was the creation of reserves to remove indigenous people from their original lands.

According to Bicalho (2010), in Brazil, a founding landmark of the Indigenous Movement can be considered the Indigenous Assemblies, organized by the Indigenous Missionary Council (CIMI) that had the opportunity to bring together several indigenous leaders of peoples that covered a great geographical distance between them. Ethnic groups that, without the assistance and funding of CIMI, would not be able to meet. Thus, there is the year 1974 as the year of the first Indigenous Assembly that took place in Diamantino - MT, two years after the creation of CIMI, where the Bororo, Xavante, Apiaka, Kaiabí, Rikbaktsa, Iranxe, Pareci and Nambikwara groups attended. The Assemblies are spaces where, for the first time, interethnic contacts allowed a perception as a collective in the struggle for recognition, providing a greater willingness to resist social action, which started to bother the Military Regime guidelines. "At the time the indigenous would rarely be showed as a historical actor, but only as endagered beings, yet to be integrated to the nacional comunity -, the indigenous would have to get their version of brazil through the Assembly" (BICALHO, 2010, p. 157).

As an organization linked to the National Conference of Bishops of Brazil (CNBB), CIMI would have created spaces for articulation based on a type of pan-indigenous association, which aimed at the self-determination of these peoples. This new role of the 
Catholic Church through CIMI is the result of its recognition in relation to mistaken evangelization policies since colonial times, and thus, based on changes made in the Second Vatican Council held from 1962 to 1965, the General Conference of the Episcopate Latin American met in Medellín, Colombia, seeking from there a new dialogue with indigenous peoples that was inspired by Liberation Theology (BICALHO, 2010).

According to Cunha (2012), in the 1970s, countless new indigenous and nonindigenous organizations emerged in support of the causes of indigenous peoples. In the following decade, the Indians were able to mobilize and organize fronts of action at the national level, which proved to be fundamental for the great historical turn that represents the rights conquered in the 1988 Constitution that legally ends the assimilationist view affirming the indigenous peoples their historical rights, including land tenure.

Two moments when the indigenous articulation was put to the test were in 1978, in an attempt to emancipate the Indians by Decree and in the beginning of the $80 \mathrm{~s}$ when FUNAI designated to it contestable ways of stipulating who is and who is not indigenous. "A relação com a FUNAl é de extrema indisposição. As falas indígenas são quase unânimes ao se posicionarem sobre a Fundação, o que denota uma total descrença quanto aquele que é o órgão principal, encarregado de nossas questões" (BICALHO, 2010, p. 166). It is in this context that in 1980 the Union of Indigenous Nations (UNI) emerges, the first truly indigenous national organization, which displeased FUNAI, which did not recognize the right to the organization outside its responsibility. According to Bicalho (2010, p. 144):

\begin{abstract}
A UNI [...] surgiu como uma organização indígena amplamente apoiada pelo CIMI, entre outras organizações de apoio, e incomodou muito o Regime por trazer à tona questões incompatíveis com a ideologia integracionista posta em prática pelo Governo: autonomia cultural, nações indígenas, autodeterminação, representatividade política, atuação de lideranças, movimento indígena, etc. Nota-se que o próprio Governo temia que a legalização da UNI conduzisse à perda de funcionalidade da FUNAI e ao crescimento do MIB [Movimento Indígena Brasileiro].
\end{abstract}

The author highlights the participation of the Union of Indigenous Nations (UNI) in the National Constituent Assembly, which was able to closely follow the procedures of the Subcommittee on Blacks, Indigenous Populations, Disabled People and Minorities in Congress, where the need for a unified discourse between indigenous leaders and organizations. With their headdresses, arrows and symbolic rites, the Indians also occupied other spaces for discussions, such as the Subcommittee on Education, Culture 
and Sport, with the help of indigenous organizations such as CIMI and the Brazilian Association of Anthropology ( $A B A$ ) where they pointed out the need differentiated education that respected their cultural traditions. The integrationist ideals were still very present in 1987, in this context we have the famous speech by Ailton Krenak, then one of the coordinators of $\mathrm{UNI}$, who when painting the face of genipap in plenary, achieved the recognition of public opinion which became decisive for indigenous demands were approved in the final text of the Constitution. This moment represents a major turning point in the history of Brazil where indigenous rights were finally officially recognized by the National State.

For Bicalho (2010), indigenous policies are about governmental action with indigenous communities while indigenous policies are about forms of action developed by the indigenous themselves and their leaders. A unanimous demand was the need for land demarcation. "Até porque é preciso lembrar que o território caracteriza o vínculo diferenciado que têm com a terra e é essencial para a sobrevivência física e cultural desses povos" (BICALHO, 2010, p. 172). The problems with the land are of various types, land already demarcated constantly invaded by farmers or squatters, land still without demarcation, land invaded and deforested for cattle raising, timber extraction, ores, etc. In this context, the land claim was the main banner, however the fight for education also had a prominent place. If this historical process represented a tenuous negotiation between democracy and authoritarianism, it is precisely because of this opposition that the Indigenous Movement remains after this conquest, in the sense of fighting for compliance with the legislation.

Thus, the 1988 Constitution, and especially the performance during the Constituent Assembly, became symbolic landmarks of the power of articulation of the Indigenous Movement. "Chegar a esses textos constitucionais favoráveis às populações indígenas - por séculos dominados e explorados por Estados nacionais que enalteciam projetos identitários homogeneizantes - não foi tarefa fácil" (BICALHO, 2010, p. 178).

Complements Bicalho (2010, p. 173):

A consciência do direito à educação também aparecia em algumas falas, já reconhecendo inclusive a importância do estudo para o alargamento de suas atuações junto ao Estado e a sociedade nacional. Dessa percepção, subjaz o protagonismo indígena na luta pelos seus direitos, e que na atualidade se tornou tão evidente. Apesar daqueles que ainda viam na formação estudantil uma forma de afastamento do índio da sua aldeia, da sua cultura, como o índio Urébépté, havia também os que acreditavam que além da terra, "o índio deve querer estudar", para poder lutar pelas suas terras, pelas suas famílias, pelos seus direitos com mais autonomia e segurança, ou ainda, "para que eles possam nos defender no futuro. 
The 1988 Constitution is a major turning point in history that began in contact between indigenous peoples and European invaders. Finally, indigenous rights were officially recognized by the National State. For Zoia (2010), it is only from a reframing resulting from the rights achieved in the 1988 Constitution, in the formalization of the right to a specific corporate project that the school will be inserted in the heart of indigenous society. According to Zoia (2010, p. 70):

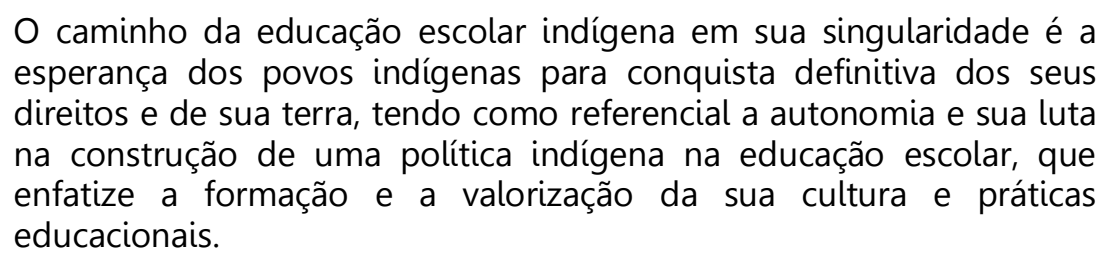

For Bicalho (2010), recognizing the Indian as a holder of collective rights and citizenship, means opposing an ideal of society that privileges the rights of the individual. The difference here disagrees with the Enlightenment reason materialized in the Universal Declaration of Human Rights. For Bicalho (2010, p. 233):

Os Estados nacionais que, como o Brasil, ao longo de suas histórias negaram as diferenças, começaram a mudar justamente após a Segunda Guerra. As décadas subseqüentes propunham um novo paradigma no qual as diferenças étnicas, de gênero, sociais, sexuais e religiosas tornaram-se bandeiras de luta de vários movimentos em torno do reconhecimento da diversidade e do respeito às diferenças.

In 2007, the UN published the United Nations Declaration on the Right of Indigenous Peoples, reaffirming as a global parameter, the right of indigenous peoples to an autonomous educational system, to the right to all forms of education offered by the State, without discrimination, in addition to the indigenous people's right to establish their own means of information in addition to guaranteeing access to non-indigenous information. For Bicalho (2010), the 1988 Constitution together with Convention No. 169 of the International Labor Organization (ILO) and the UN Declaration on Indigenous Peoples brought great advances in relation to the economic, social and cultural rights of Indians at the international level. Of vital importance, they affirm the right to education and information, to the territory and culture.

According to Gallois (2016), the search for an authentic way of making the school indigenous was the subject of debate among indigenous people, educators and anthropologists at the Seminar on Cultural Policies and Indigenous Peoples: the school 
and other problems held in 2013. Non- indigenous people seemed to have more radical criticisms regarding schooling and intercultural ideas than indigenous people themselves in the relationship between school and traditional knowledge. Indigenous people were interested in a more concrete analysis of their real problems of formation, access, permanence, etc.

From the perception of the school as a powerful tool in the cultural resistance of indigenous peoples, Munduruku (2017) recognizes advances regarding indigenous school education in the sense that the training of indigenous teachers can contribute to an autonomous pedagogical conception among peoples. In the words of the indigenous intellectual Daniel Munduruku (2017, p. 3):

Entendo que há uma preocupação prática nos diversos programas de educação indígena espalhados pelo Brasil afora, sejam eles operados pelas esferas governamentais ou não-governamentais. Muitos desses programas têm partido do princípio que é preciso fortalecer a autoria como uma forma de fortalecer também a identidade étnica dos povos que atendem. Isso é muito positivo se a gente entender que a autoria, aqui defendida, signifique que estes povos possam num futuro próximo, criar sua própria pedagogia, seu modo único de trafegar pelo universo das letras e do letramento. Só assim posso imaginar que valha a pena o esforço dos que se põem a trilhar este caminho. Se estes grupos de fato acreditarem que estão criando pessoas para a autonomia intelectual e se abrirem espaço na sociedade para a livre expressão deste pensamento, então eles estarão, realmente, fortalecendo a autoria e apresentando um caminho novo para as manifestações culturais, artísticas, políticas, lúdicas e religiosas dos nossos povos indígenas. Caso contrário, estarão levando nossa gente para o mesmo buraco em que o pensamento quadrado ocidental se meteu e, neste caso, estarão sendo piores que o regime ditatorial que almejava exterminar as identidades transformando-as numa única e cínica identidade nacional brasileira.

If, in the first centuries of cultural contact, the school was inserted into indigenous communities as a strange institution, disconnected from local culture and ethnocidal in its mission to Christianize indigenous peoples, today it is a powerful tool for the preservation of their traditional culture. This contradiction would be inherent in school education, "a escola é percebida ao mesmo tempo como instrumento de empoderamento para a 'autonomia' e também como uma armadilha para a domesticação de conhecimentos" (GALLOIS, 2016, p. 509). One of the effects of the appropriation of culture in the context of school education is "fazer delas [escolas] um espaço para o exercício da política indígena, que consiste inclusive em aprender a política dos brancos, para daí participar mais ativamente do movimento indígena" (GALLOIS, 2016, p. 512). 
The ethnocide present in the ideology of integration of indigenous peoples into the mercantilist and Christian order of the West is represented in a conception of education supposedly redemptive of the civilizing backwardness of indigenous peoples. Thus denounces Munduruku (2017), as he points out that this education would have the ultimate objective of destroying indigenous ethnic identity and giving capital dominion over their lands. The author affirms that the Western being understands nature as external to him, ignoring his writing when trying to take possession of it. This idea is inserted in a logic of domination of the European and in how it imposed its view of the world from colonial domination. According to Munduruku (2017, p. 2-3):

\begin{abstract}
Foi-se criando uma necessidade nos jovens nativos de apreender conceitos e teorias que não cabem no pensar holístico e circular de seus povos. Esta agressão ao sistema mental indígena, fruto de uma história da qual não somos culpados, mas sobre qual temos responsabilidade, acaba se perpetuando nas novas políticas inclusivistas levados a efeito por governos nas três esferas. Conclusão: nossos jovens se vêm obrigados a aceitar como inevitável à necessidade de ler e escrever códigos das quais prefeririam não aprender e não lhes é dado o direito de recusar sob a acusação de preguiça ou descaso para com a 'boa vontade' dos governos e governantes.
\end{abstract}

The school that has the indigenous as its protagonist and the knowledge that will be taught there emerges from the important performance of the indigenous social movements. For Zart (2012, p. 25), "os conhecimentos [são] como processos dinâmicos, e, socialmente os grupos definem a verossimilhança dos conhecimentos, isto é, o conhecimento é verdadeiro na relação social, e não numa pré-definição", thus defining knowledge as historically constructed within symbolic relations present in forms of language. "[...] o conhecimento é o que os atores sociais definem como sendo verdadeiro, válido e que será legitimado e socialmente aceito" (ZART, 2012, p. 25). Such an eminently political and cultural reality. Zart continues (2012, p. 25) "[...] definir socialmente a realidade que foi construída é admitir relações sociais que demonstram não somente a diversidade das sociedades, mas ilustram também as suas contradições e arbitrariedades, portanto, as desigualdades sociais".

Passos (2010) is also attentive to this political character of education, by associating resistance to the struggle for indigenous rights in their recognition of themselves as a heterogeneous group. "A revolta é um símbolo de luta, sobretudo quando nasce da descoberta da injustiça, e que necessita para além do instinto de classe a consciência de classe" (PASSOS, 2010, p. 34).

In discussions involving anthropologists and indigenous people, the need for bilingual education and health care for indigenous people was constantly raised. The so- 
called intercultural school was seen as essential in the appropriation of cultural and historical rights of indigenous people (BICALHO, 2010). The national political scene had the indigenous "como um novo ator político e social, que começou a organizar politicamente, consciente da sua cultura, da sua história, dos seus direitos e da necessidade de mobilização do grupo como meio de ruptura com a condição de colonizado". (BICALHO, 2010, p. 174).

The school resignified itself from the conception of the right to a corporate project based on its autonomy and protagonism, thus seeking the Brazilian state, to act in the formation of indigenous teachers who can teach in their original language. This position of the school in the indigenous society is linked to the recognition of the indigenous right to their culture and the understanding that public policies must be based on the autonomy and protagonism of the indigenous. For Zoia (2010), the school will become fundamental in the process of valuing and preserving indigenous culture, acting in the emancipation of these peoples from the hegemonic cultural order. The result of this is the strengthening, for example, of the language, where school education becomes an instrument for reaffirming the ancestral language. According to Zoia (2010, p. 70):

O caminho da educação escolar indígena em sua singularidade é a esperança dos povos indígenas para conquista definitiva dos seus direitos e de sua terra, tendo como referencial a autonomia e sua luta na construção de uma política indígena na educação escolar, que enfatize a formação e a valorização da sua cultura e práticas educacionais.

This meaning and sense is highlighted by Zoia (2010), because as the researcher indicates, many indigenous communities started to see in the school a space that is conducive both to access to general knowledge arising from post-colonial needs, and to the valorization of historically constructed knowledge, a space that would be constituted based on the cultural specificities of each people in their ethnic affirmation.

\section{Conclusion}

From the readings carried out through bibliographic research, issues of paramount importance were covered for indigenous school education in Brazil, from the organization as a movement to the conquest of rights on which the importance of intercultural school in indigenous communities was based. The history of the indigenous people in Brazil is a history of violence, genocide, ethnocide and epistemicide, but also of great cultural resistance that has lasted for more than five centuries. As a new paradigm, in the relationship with the surrounding society and the Brazilian national 
state, the performance of the indigenous movement organized at national level is manifested in the constitutional charter.

Intercultural education represents a possibility of resignification in relation to school with indigenous peoples, and may represent an instrument of social, cultural and political empowerment. Despite these advances, it is important to consider the situation of marginalization that generally characterizes the situation of indigenous people in the post-colonial American continent. Indigenous peoples are still very underrepresented in representative political instances, and their hard-won rights live with constant threats from different socioeconomic interests.

\section{References}

BERGAMASCHI, Maria Aparecida. Intelectuais indígenas, interculturalidade e a educação. Revista Tellus, Campo Grande-MS, ano 14, n. 26, jan./ jul. 2014.

BICALHO, Poliene Soares dos Santos. Protagonismo indígena no Brasil: movimento, cidadania e direitos (1970-2009). 2010. Tese (Doutorado em História). Instituto de Ciências Humanas, Departamento de História, Universidade de Brasília, Brasília, 2010.

CUNHA, Manuela Carneiro da. Índios no Brasil: história, direitos e cidadania. São Paulo: Claro Enigma, 2012.

FAVRE, Henry. El indigenismo. México: Fondo de Cultura Económica, 1998.

FLEURI, Reinaldo Matias. Interculturalidade e educação. Revista Brasileira de Educação, n. 23. 2003.

GALLOIS, Dominique Tilkin. A escola como problema: algumas posições. In: CUNHA, Manuela Carneiro da; CESARINO, Pedro de Niemeyer. (Orgs.). Políticas culturais e povos indígenas. São Paulo: Unesp, 2016.

MUNDURUKU, Daniel. A escrita e a autoria fortalecendo a identidade. 2017. Disponível em:

https://pib.socioambiental.org/pt/A_escrita_e_a_autoria_fortalecendo_a_identidad e. Acesso em: 03 out. 2020.

PASSOS, Luiz Augusto. Cultura: flecha humana e cósmica que aponta o caminho para os sentidos. IN: GRANDO, Beleni Saléte; PASSOS, Luiz Augusto. (Orgs.). O eu e o outro na escola: contribuições para incluir a história e a cultura dos povos indígenas na escola. Cuiabá: EdUFMT, 2010.

SILVA, Maria do Socorro Pimentel da; HERBETTA, Alexandre. Educação intercultural e interepistêmica: desafios políticos para (e a partir) da escola indígena. In: LANDA, Mariano Baéz; HERBETTA, Alexandre Ferraz. (Orgs.). Educação indígena e 
interculturalidade: um debate epistemológico e político. Goiânia: Imprensa Universitária, 2017.

ZART, Laudemir Luiz. Produção social do conhecimento na experiência do curso de agronomia dos movimentos sociais do campo (CAMOSC): interação da Unemat e de movimentos sociais do campo. 2012. Tese (Doutorado em Política Científica e Tecnológica). Instituto de Geociências, Universidade Estadual de Campinas, Campinas-SP, 2012.

ZOIA, Alceu. A questão da educação indígena na legislação brasileira e a escola indígena. IN: GRANDO, Beleni Saléte; PASSOS, Luiz Augusto. (Orgs.). O eu e o outro na escola: contribuições para incluir a história e a cultura dos povos indígenas na escola. Cuiabá: EdUFMT, 2010. 


\section{Crevisto \\ Observatório}

\section{RESUMO:}

This text presents a critical analysis of Enem's official dissemination campaigns in the years 2019 and 2020 amidst a scenario of political tensions between government and federal universities, also marked by the coronavirus pandemic. The study shows a partial representation, in the scope of Brazilian government advertising, sciences and higher education, characterized mainly by the overvaluation of courses in Health Sciences and courses traditionally valued by the labor market, such as Law and Engineering, in contrast to the relative invisibility of Human, Social Sciences and other areas of knowledge.

PALAVRAS-CHAVE: Communication; Science; Higher Education; Advertising; Government Advertising.

\begin{abstract}
RESUMEN:
Los movimentos sociales tuvieron gran participación como agentes políticos a lo largo del siglo $\mathrm{XX}$, es a partir de esta articulación a nível latinoamericano que la perspectiva de la interculturalidade cobra fuerza dentro de la educación escolar indígena, que busca entender la escuela dentro de las desigualdades poscoloniales. El movimiento indígena brasileño comenzó a organizarse en la década de 1970, con la Unión de Naciones Indígenas (UNI) jugando um papel principal en la carta constitucional de 1988, que sustentará los derechos educativos relacionados con la escuela intercultural dentro de un proyecto social específico.
\end{abstract}

PALABRAS-CLAVES: Movimientos sociales. Educación intercultural. Población indígena. 